\title{
PENGARUH KEPEMILIKAN INSTITUSIONAL, KOMITE AUDIT DAN UKURAN PERUSAHAAN TERHADAP KINERJA PERUSAHAAN
}

\author{
Mulia Alim', Uniq Destriana ${ }^{2}$ \\ Universitas Muhammadiyah Tangerang \\ alim17mt@gmail.com
}

Keyword
Financial Performance, Companies,

Investors

\section{Abstract}

This study was to determine whether the audit committee of institutional ownership and firm size (size) positive effect on the performance of companies, both partially and simultaneously. Agency theory is the theory behind a conflict of interest between managers and owners (shareholders). The manager as agent and owner of the company as a principal. Agents often misuse company resources with an excessive amount. Agency conflict is a situation where managers often make decisions that benefit themselves rather than the interests of shareholders. While the minimal information that principals have difficulty to find out if the agent had acted in accordance with the wishes of the principal or even hurt the company.

C2016 JMB, All right reserved

\section{PENDAHULUAN}

Penerapan corporate governance dalam suatu perusahaan begitu penting hal ini dilakukan untuk mencegah terjadinya hal hal yang dapat merugikan pemilik perusahaan (pemegang saham). Setiap pemilik perusahaan tentu berkeinginan agar perusahaannya dapat terus maju dan berkembang agar hal tersebut dapat terwujud, maka perusahaan dituntut untuk memberikan perhatian lebih pada performa atau kinerjanya. Kinerja adalah hasil kerja yang dapat dicapai oleh seseorang atau kelompok orang dalam suatu perusahaan sesuai dengan wewenang dan tanggung jawab masing-masing dalam upaya pencapaian tujuan perusahaan secara legal, tidak melanggar hukum dan tidak bertentangan dengan moral dan etika. (Rivai \& Basri, 2004:16).

Bagi para investor, informasi mengenai kinerja perusahaan merupakan media yang dapat digunakan untuk memprediksikan prospek perusahaan di masa mendatang. Menurunnya kinerja di dalam perusahaan akan mengakibatkan menurunnya laba yang dihasilkan, jika laba yang dihasilkan menurun maka investor enggan menanamkan modalnya di dalam perusahaan tersebut. Laporan keuangan dalam hubungannya dengan kinerja sering dijadikan dasar penilaian kinerja perusahaan (Ujiyantho et al., 2007). Karena dengan melihat laporan keuangan dapat diukur keberhasilan operasi perusahaan untuk suatu periode tertentu.

Salah satu ukuran kinerja perusahaan adalah Return on Equity (ROE). ROE adalah ukuran profitabilitas perusahaan penting yang mengukur pengembalian untuk pemegang saham. Meningkatnya kinerja perusahaan dapat meningkatkan laba yang dihasilkan perusahaan. Jika laba meningkat maka perusahaan di anggap mampu memberikan dividen kepada pemegang saham. Perusahaan yang berkinerja baik akan memperoleh respon positif dari pasar melalui peningkatan harga saham perusahaan dan disinyalir mampu menjamin kesejahteraan pemiliknya. Namun pada prakteknya seringkali terjadi hambatan - hambatan dalam mencapai tujuan perusahaan. Untuk mengatasi hambatan hambatan tersebut maka perusahaan perlu mempunyai suatu mekanisme untuk 
meminimalisir hambatan - hambatan tersebut, untuk meyakinkan investor akan transparansi dan akuntanbilitas dari perusahaan. sehingga investor yakin atas perolehan pendapatan (return) dari investasinya. mekanisme tersebut dikenal dengan sebutan corporate governance.

\section{TINJAUAN PUSTAKA}

\section{Ukuran Perusahaan}

Ukuran perusahaan adalah skala besar kecilnya perusahaan yang dapat diklasifikasikan berdasarkan berbagai cara antara lain dengan ukuran pendapatan, total aset, dan total ekuitas (Brigham dan Houston, 200I) dalam (warianto, 20I3). Semakin besar ukuran perusahan maka semakin besar pula dana yang dikelola oleh perusahaan tersebut. Menurut (Jogiyanto, 2003) dalam (Reyhan, 2014) Perusahaan yang besar dianggap mempunyai risiko yang lebih kecil dibandingkan dengan perusahaan yang kecil. Maka dari itu investor biasanya lebih tertarik untuk menanamkan modalnya di perusahaan besar, karena perusahaan besar dianggap lebih mempertahankn dan meningkatkan kinerjanya.

\section{Kinerja Perusahaan}

Kinerja adalah hasil kerja yang dapat dicapai oleh seseorang atau kelompok orang dalam suatu perusahaan sesuai dengan wewenang dan tanggung jawab masing-masing dalam upaya pencapaian tujuan perusahaan secara legal, tidak melanggar hukum dan tidak bertentangan dengan moral dan etika. (Rivai \& Basri, 2004:16).

Perusahaan dalam mengelola dan mengalokasikan sumber dayanya di ukur dengan kinerja perusahaan. Untuk mencapai hasil kinerja yang optimal dalam perusahaan maka diperulakan kerja sama antara pihak-pihak yang berkepentingan dalam perusahaan. Maka dari itu kinerja perusahaan merupakan hal penting yang harus dicapai oleh setiap perusahaan.

Bagi para investor, informasi mengenai kinerja perusahaan merupakan media yang dapat digunakan untuk memprediksikan prospek perusahaan di masa mendatang. Laporan keuangan dalam hubungannya dengan kinerja sering dijadikan dasar penilaian kinerja perusahaan karena dengan melihat laporan keuangan dapat diukur keberhasilan operasi perusahaan untuk suatu periode tertentu (Ujiyantho et al., 2007) dalam (Suciningsih et al. 2014).
Ada banyak rasio dalam mengukur kinerja perusahaan salah satunya yaitu dengan Rasio profitabilitas. Rasio profitabilitas rasio untuk mengukur seberapa besar kemampuan perusahaan memperoleh laba baik dalam hubungan penjualan, aset maupun laba bagi modal sendiri. Rasio profitabilitas dibagi menjadi enam antara lain: Gross profit margin (GRM), net profit margin (NPM), operating return on assets (OPROA), return on assets (ROA), return on equity $(R O E)$, operating ratio (OR).

Tabel I Faktor-faktor yang Mempengaruhi Kinerja Perusahaan

\begin{tabular}{|c|c|c|}
\hline No & $\begin{array}{l}\text { Faktor yang } \\
\text { berpengaruh }\end{array}$ & Peneliti (Tahun) \\
\hline 1 & $\begin{array}{l}\text { Kepemilikan } \\
\text { Manajerial }\end{array}$ & $\begin{array}{l}\text { Putu Ayu Winda Adi Puteri } \\
(20 \mid 2)\end{array}$ \\
\hline 2 & $\begin{array}{l}\text { Ukuran } \\
\text { Perusahaan }\end{array}$ & $\begin{array}{l}\text { Togi Primayoga Pandenius } \\
\text { Siagian, P. dan Basuki } \\
\text { Hadiprajit (20I3) }\end{array}$ \\
\hline 3 & $\begin{array}{l}\text { Proporsi Dewan } \\
\text { Komisaris }\end{array}$ & Siti Muntiah (20|4) \\
\hline 4 & $\begin{array}{l}\text { Kepemilikan } \\
\text { Institusional }\end{array}$ & $\begin{array}{l}\text { Putu Ayu Winda Adi Puteri } \\
(20 \mid 2)\end{array}$ \\
\hline 5 & Struktur Modal & $\begin{array}{l}\text { Khaira Amalia Fachrudin } \\
(20 I I)\end{array}$ \\
\hline
\end{tabular}

\section{Hipotesis}

\section{Pengaruh kepemilikan institusional terhadap kinerja Perusahaan}

Kepemilikan institusional merupakan kepemilikan saham oleh pemerintah, institusi keuangan, institusi berbadan hukum, institusi luar negeri, dana perwalian serta institusi lainnya pada akhir tahun (Shien, et.al. 2006) dalam Winanda (2009). Kepemilikan institusional mempunyai peranan penting dalam memonitor manajemen. Kepemilikan institusional dipercaya dapat meminimalisir konflik kepentingan yang terjadi di dalam suatu perusahaan. Hasil penelitian yang dilakukan oleh putu (20I2) menemukan bahwa kepemilikan institusional tidak berpengaruh pada kinerja perusahaan manufaktur. Muntiah (2014) juga melakukan penelitian yang hasilnya bahwa kepemilikan institusional berpengaruh signifikan terhadap kinerja perusahaan. Sedangkan Mahaputri (2014) dalam penelitiannya menemukan bahwa Kepemilikan Institusional berpengaruh negatif signifikan terhadap kinerja perusahaan. Kepemilikan institusional tidak berhasil meningkatkan kinerja keuangan perusa.haan. Dari penelitian tersebut terdapat ketidakkonsistenan temuan hasil penelitian maka rumusan hipotesis dalam penelitian ini sebagai berikut: 
$\mathrm{HI}$ : Kepemilikan institusional berpengaruh positif terhadap kinerja perusahaan.

\section{Pengaruh komite audit terhadap kinerja perusahaan}

Hasil penelitian yang dilakukan oleh Puteri (20I2) menemukan bahwa komite audit tidak berpengaruh pada kinerja perusahaan manufaktur. Sedangkan Susanti (20II) dalam penelitiannya menemukan bahwa Komite audit berpengaruh secara negatif terhadap kinerja perusahaan. Sedangkan penelitian yang dilakukan oleh Muntiah (2014) menemukan bahwa komite audit berpegaruh positif terhadap kinerja perusahaan. Dari penelitian tersebut terdapat ketidak konsistenan temuan hasil penelitian maka rumusan hipotesis dalam penelitian ini sebagai berikut:

$\mathrm{H} 2$ : Komite audit berpengaruh positif terhadap kinerja perusahaan.

\section{Pengaruh ukuran perusahaan terhadap kinerja perusahaan}

Ukuran perusahaan didefiniskan sebagai jumlah aset yang dimiliki oleh perusahaan dan dirumuskan dengan logaritma natural total aset (LnUkuran). Faktor ini menerangkan bahwa suatu perusahaan yang mapan dan besar memiliki akses untuk meningkatkan kinerja perusahaan, sedangkan perusahaan kecil tidak mudah untuk meningkatkan kinerja perusahaan. Penelitian Togi et.al. (20I3) menemukan bahwa ukuran perusahaan memiliki pengaruh terhadap kinerja perusahaan yang diukur dengan ROE, artinya jika jumlah asset yang dimiliki perusahaan semakin besar maka kinerja perusahaan semakin meningkat. Penelitian Khaira Amalia Fachrudin menemukan bahwa ukuran perusahaan tidak berpengaruh signifikan terhadap kinerja perusahaan. Berdasarkan uraian tersebut, terdapat ketidakkonsistenan temuan hasil penelitian maka rumusan hipotesis dalam penelitian ini sebagai berikut:

H3 : Ukuran perusahaan berpengaruh positif terhadap kinerja perusahaan.

\section{Pengaruh kepemilikan institusional, komite audit, ukuran perusahaan terhadap kinerja perusahaan}

Kepemilikan institusional cenderung menghabiskan sebagian besar waktu mereka untuk melakukan analisis investasi dan memiliki akses atas informasi yang terlalu mahal perolehannya bagi investor individual (Murwaningsari, 2009) dalam (Putri, 20I2). Atas keunggulan yang dimiliki tersebut Kepemilikan Institusional sebagai pihak principal yang bertanggungjawab atas pengendalian perusahaan yang dibantu oleh komite audit dengan pengelolaan aset perusahaan tertentu memberikan kompleksivitas yang perlu diperhitungkan untuk mencapai corporate governance. Di samping itu, pengertian corporate governance menjelaskan bahwa adanya suatu sistem dan proses yang melibatkan proporsi Kepemilikan institusional, komite audit dan ukuran perusahaan untuk menjalankan aktivitas dalam mencapai tujuan perusahaan. Dalam menjalankan aktivitas perusahaan, pengelolaan yang baik diwujudkan dalam kinerja perusahaan yang terpadu. Maka dari itu, penelitian ini akan melihat pengaruh corporate governance secara bersama-sama terhadap kinerja perusahaan. Sesuai dengan penjelasan diatas maka hipotesis penelitian ini adalah

H4 : Kepemilikan institusional, Komite audit, Ukuran perusahaan berpengaruh positif terhadap kinerja perusahaan.

\section{METODE PENELITIAN}

Penelitian ini menggunakan pendekatan penelitian kuantitatif. Populasi yang digunakan dalam penelitian ini adalah perusahaan pertambangan yang terdaftar di Bursa Efek Indonesia selama tahun 2012 sampai dengan tahun 2014 sejumlah 42 perusahaan. Teknik pengambilan sampel dalam penelitian ini adalah non probability sampling dengan metode purposive sampling. Data yang di gunakan dalam penelitian ini adalah data sekunder yaitu laporan tahunan perusahaan yang diperoleh melalui situs resmi Bursa Efek Indonesia dengan menggunakan metode dokumentasi. laporan tahunan perusahaan pertambangan periode tahun 2012 sampai dengan tahun 2014 .

\section{HASIL PENELITIAN DAN PEMBAHASAN}

Berdasarkan proses pemilihan sampel yang telah disebutkan diatas, maka sampel yang digunakan adalah 12 perusahaan pertambangan setiap tahun pada periode tahun 2010 sampai dengan 2014. Sehingga total observasi selama periode 2010 sampai dengan tahun 2014 berjumlah 60 sampel. Berikut ini disajikan daftar perusahaan pertambangan yang dijadikan sampel selama periode 2010-2014 : 
Tabel 2. Kriteria Sampel Penelitian

\begin{tabular}{|c|l|c|}
\hline No. & \multicolumn{1}{|c|}{ Keterangan } & Jumlah \\
\hline I & $\begin{array}{l}\text { Jumlah perusahaan } \\
\text { pertambangan yang terdaftar } \\
\text { di Bursa Efek Indonesia } \\
\text { selama tahun 20 I0- 20 I4 }\end{array}$ & 42 \\
\hline 2 & $\begin{array}{l}\text { Perusahaan yang tidak } \\
\text { menerbitkan laporan tahunan } \\
\text { maupun laporan keuangan } \\
\text { secara lengkap pada tahun } \\
\text { 20I0-20 I4 }\end{array}$ & $(9)$ \\
\hline 3 & $\begin{array}{l}\text { Perusahaan yang tidak } \\
\text { menggunakan satuan mata } \\
\text { uang rupiah pada tahun } \\
\text { penelitian 20 I0-20I4 }\end{array}$ & $(21)$ \\
\hline Total perusahaan yang dijadikan \\
sampel
\end{tabular}

Uji normalitas dengan One Sample Kolmogorov Smirnov Test dilakukan terlebih dahulu untuk menguji normalitas data dari masing-masing variable independen

Tabel 3. Uji Normalitas

\begin{tabular}{llr}
\hline \multicolumn{3}{c}{ Uji One-Sample Kolmogorov-Smirnov Test } \\
& $\begin{array}{c}\text { Unstandardized } \\
\text { Residual }\end{array}$ \\
\hline $\mathrm{N}$ & Mean & 60 \\
Normal & Std. & $0 \mathrm{E}-7$ \\
Parameters, $\mathrm{b}$ & Deviation & .14855164 \\
Most Extreme & Absolute & .116 \\
Differences & Positive & .062 \\
& Negative & -.116 \\
Kolmogorov-Smirnov Z & .901 \\
Asymp. Sig. (2-tailed) & .391 \\
a. Test distribution is Normal. & \\
b. Calculated from data. & \\
\hline
\end{tabular}

Besarnya nilai Kolmogorov-Smirnov adalah 0,90 I dan nilai signifikansi $>0,05$, sehingga dapat disimpulkan bahwa data terdistribusi secara normal.

\section{Uji Multikolonieritas}

Berdasarkan hasil pengujian terhadap sampel dalam penelitian ini, maka diperoleh hasil uji multikolonieritas yang dapat dilihat dari nilai Tolerance dan Variace Inflaction Factor (VIF) sebagai berikut:
Tabel 4. Uji Multikolinieritas

\begin{tabular}{cccc}
\multicolumn{4}{c}{ Coefficients $^{\mathbf{a}}$} \\
\hline \multirow{3}{*}{ Model } & & \multicolumn{2}{c}{ Collinearity Statistics } \\
\cline { 3 - 4 } & & Tolerance & VIF \\
\cline { 3 - 4 } $\mathrm{I}$ & $\mathrm{INST}$ & .982 & 1.018 \\
& $\mathrm{KA}$ & .664 & 1.506 \\
& $\mathrm{SIZE}$ & .663 & 1.509 \\
\hline
\end{tabular}

a. Dependent Variable: ROE

Model regresi yang baik adalah apabila tidak terjadi multikolonieritas dengan asumsi nilai Tolerance $\geq 0,10$ dan VIF $\leq 10$. Berdasarkan hasil yang diperoleh dari tabel diatas, dapat dilihat bahwa nilai Tolerance dalam penelitian ini memiliki nilai $\geq 0,10$ dan VIF $\leq 10$, sehingga dapat disimpulkan bahwa model regresi dalam penelitian ini terbebas dari asumsi multikolonieritas.

\section{Uji Autokorelasi}

Uji autokorelasi ini bertujuan untuk menguji apakah dalam model regresi linier ada korelasi antar kesalahan pengganggu pada periode $t$ dengan kesalahan pengganggu $t$. ıperiode sebelumnya. Berikut hasil dari uji autokorelasi model regresi:

Tabel 5. Uji Autokorelasi

\begin{tabular}{lrrrrr}
\hline Model & $\mathrm{R}$ & $\begin{array}{c}\text { Model Summary } \\
\text { R }\end{array}$ & $\begin{array}{c}\text { Adjusted } \\
\text { R Square }\end{array}$ & $\begin{array}{c}\text { Std. Error } \\
\text { of the } \\
\text { Estimate }\end{array}$ & $\begin{array}{l}\text { Durbin- } \\
\text { Watson }\end{array}$ \\
\hline I & $.4 I I^{a}$ & .169 & .124 & .15248 & 2.063 \\
\hline $\begin{array}{l}\text { a. Predictors: (Constant), SIZE, INST, JKA } \\
\text { b. Dependent Variable: ROE }\end{array}$
\end{tabular}

Berdasarkan hasil output diatas di dapat nilai DW yang dihasilkan sebesar 2,063. Sedangkan dari tabel DW dengan signifikansi 0,05 dan jumlah data $(n)=60$, serta $k=3$ ( $k$ adalah jumlah variabel independen) diperoleh nilai $d_{L}$ sebesar 1,4797 dan du sebesar 1,6889. Dengan demikian dapat disimpulkan bahwa terdapat autokorelasi positif dalam penelitian ini karena hasil dari tabel diatas dan nilai DW sebesar 2,063 . Oleh karena nilai DW 2,063 terletak antara batas atas (du) I,6889 dan (4 - du) $2,3 \mathrm{III}$, Oleh karna $d u<d w<(4-d u)$ atau $\mathrm{I}, 6889<2,063<2,3 \mathrm{III}$ maka dapat disimpulkan model regresi yang dibuat terbebas dari penyimpangan asumsi klasik autokorelasi. 


\section{Hipotesis}

Tabel 6 Hipotesis Uji $t$

\begin{tabular}{|c|c|c|c|c|c|c|}
\hline & \multirow{2}{*}{$\begin{array}{l}\text { Hipotesis } \\
(\mathrm{Y}=\mathrm{ROE})\end{array}$} & \multicolumn{2}{|c|}{ Hasil Uji $t$} & \multirow{2}{*}{\multicolumn{3}{|c|}{ Keterangan Hasil }} \\
\hline & & Nilai $t$ & Sig. & & & \\
\hline \multirow[t]{2}{*}{$\mathrm{HI}$} & Kepemilikan & -0.832 & 0.409 & $<\mathrm{t}_{\text {tabel }}$ & $>0,05$ & Tidak \\
\hline & institusional & & & & & Signifikan \\
\hline \multirow[t]{2}{*}{$\mathrm{H} 2$} & Komite audit & 0.620 & 0.538 & $<t_{\text {tabel }}$ & $>0,05$ & Tidak \\
\hline & & & & & & Signifikan \\
\hline $\mathrm{H} 3$ & Ukuran perusahaan & 2.871 & 0,006 & $>t_{\text {tabel }}$ & $<0,05$ & Signifikan \\
\hline
\end{tabular}

Berdasarkan hasil pengujian di atas, dengan melihat nilai sigifikansinya sebesar 0,409 dan nilai $t$ sebesar $-0.832<1.67252$, maka dapat disimpulkan bahwa kepemilikan institusional yang diukur dengan jumlah saham yang dimiliki oleh institusi dibagi dengan jumlah saham yang beredar tidak memiliki pengaruh yang signifikan terhadap kinerja perusahaan artinya Hipotesis I ditolak. Temuan ini tidak sejalan dengan temuan Mahaputri (2014) yang sebelumnya membuktikan adanya pengaruh negatif signifikan antara kepemilikan institusional dan kinerja perusahaan. Apabila pemegang saham mempunyai saham yang kecil maka terdapat kesempatan kecil pula bagi pemegang saham untuk memonitor manajemen perusahaan. sehingga kepemilikan institusional belum dapat dikatakan sebagai mekanisme untuk meningkatkan kinerja perusahaan.

Sementara itu berdasarkan hasil pengujian diatas menunjukkan bahwa nilai signifikasi dari $\mathrm{X} 2$ jumlah komite audit yang lebih besar dari 0,05 , yaitu sebesar 0,538 . Dengan demikian dapat disimpulkan bahwa jumlah komite audit tidak memiliki pengaruh yang signifikan terhadap kinerja perusahaan, baik jika dilihat dari nilai $t_{\text {hitung }}$ yang lebih kecil dari $t_{\text {tabel }}$, yaitu sebesar $0.620<1.67252$, maka Hipotesis 2 ditolak. Komite audit di ukur dengan jumlah komite audit yang ada di dalam perusahaan. Penelitian ini tidak sesuai dengan penelitian (Muntiah, 2014). Yang membuktikan bahwa variabel komite audit berpengaruh positif dan signifikan terhadap kinerja perusahaan. Semakin banyak komposisi komite audit maka kinerja keuangan akan terawasi dengan baik sehingga kinerja akan meningkat. Komite audit ditempatkan sebagai mekanisme pengawasan antara manajemen dengan pihak eksternal, sehingga komite audit dipandang dapat meningkatkan kinerja perusahaan melalui pengawasan tersebut.

Berdasarkan hasil pengujian diatas menunjukkan bahwa hipotesis 3 , yaitu variabel ukuran perusahaan mempunyai pengaruh positif terhadap kinerja perusahaan. Hasil ini didukung oleh penelitian sebelumnya yang dilakukan oleh Togi primayoga (2013) yang menyatakan bahwa variabel ukuran perusahaan berpengaruh positif signifikan terhadap kinerja perusahaan. $\mathrm{H} 3$ diterima, dengan nilai $t_{\text {hitung }}$ sebesar 2.87 I > I.67252 dan nilai siginifikansi sebesar 0,006. Dengan demikian dapat dikatakan bahwa ukuran perusahaan memiliki pengaruh psitif terhadap kinerja perusahaan. Hal ini berarti perusahaan dengan skala besar tentu akan mendapatkan perhatian dari banyak pihak seperti para investor. Perusahaan yang besar dianggap mempunyai risiko yang lebih kecil dibandingkan dengan perusahaan yang kecil. Maka dari itu investor biasanya lebih tertarik untuk menanamkan modalnya di perusahaan besar, karena perusahaan besar dianggap lebih mempertahankan dan meningkatkan kinerjanya.

Tabel ANOVAa

\begin{tabular}{cccccc}
\hline Model & Sum of Squares & Df & Mean Square & $\mathrm{F}$ & Sig. \\
\hline Regression & .265 & 3 & .088 & 3.795 & $.015 \mathrm{~b}$ \\
Residual & 1.302 & 56 & .023 & & \\
Total & 1.567 & 59 & & & \\
\hline
\end{tabular}

a. Dependent Variable: ROE

b. Predictors: (Constant), SIZE, INST, JKA

Berdasarkan hasil dari tabel diatas dapat dilihat bahwa nilai $F_{\text {hitung }}$ sebesar 3,795 dan apabilia dilihat dari nilai $F_{\text {tabel }}$ menggunakan signifikansi $5 \%(\alpha=0,05)$ dan degree of freedom 
$d f I(k-I)$ dan $d f 2(n-k)$, yaitu $d f I=(4-I)=3$, dan $d f 2=60-4=56$, diperoleh nilai Ftabel sebesar 2,77, sehingga dapat disimpulkan bahwa nilai $F_{\text {hitung }}>F_{\text {tabel, }}$ yaitu sebesar $3,795>2,77$. Hal ini berarti secara simultan semua variabel independen dalam penelitian ini dapat berpengaruh terhadap variabel dependen secara signifikan. Dengan demikian hipotesis $4(\mathrm{H} 4)$ diterima.

\section{PENUTUP}

Berdasarkan hasil analisis data dan pembahasa, hasil uji statistik parsial (uji $t$ ) menunjukkan bahwa satu dari tiga variabel dalam penelitian ini, yaitu ukuran perusahaan berpengaruh secara signifikan terhadap kinerja perusahaan, sementara dua variable lainnya yaitu kepemilikan institusional dan komite audit tidak dapat membuktikan adanya pengaruh yang signifikan terhadap kinerja perusahaan. Berdasarkan hasil dari Uji signifikansi simultan (uji F) menunjukkan ketiga variable independen yaitu, kepemilikan institusional, komite audit dan ukuran perusahaan secara bersama-sama dapat berpengaruh secara signifikan terhadap kinerja perusahaan.

\section{DAFTAR PUSTAKA}

Ghozali, Imam. 2012. Aplikasi Analisis Multivariate dengan program SPSS edisi 6. Badan Penerbit Universitas Diponegoro, Semarang.

Priyatno, Duwi. 2012. Cara Kilat Belajar Analisis Data dengan SPSS 20. Andi, Yogyakarta.

Sutrisno. 20I2. Manajemen Keuangan Teori Konsep \& Aplikasi. Ekonisia Fakultas Ekonomi UII, Yogyakarta.

Sugiyono. 201I. Metode Penelitian Kuantitatif, Kualitatif, dan R\&D. Alfabeta, Bandung.

Baumol, W.J. (1959). Business Behavior, Value and Growth. New York, Macmillan.

Jensen, Michael C. (1979). "Tests of Capital Market Theory and Implications of the Evidence."Handbook of Financial Economics

Jensen, Michael $\mathrm{C}$. and William H. Meckling (1978). "Can the Corporation Survive?" Financial Analysts Journal (January-February) 